\title{
Local habitat and landscape affect Ixodes ricinus tick abundances in forests on poor, sandy soils
}

\author{
Wesley Tack ${ }^{\mathrm{a}^{*}}$, Maxime Madder ${ }^{\mathrm{b}, \mathrm{c}}$, Lander Baeten ${ }^{\mathrm{a}}$, Margot Vanhellemont ${ }^{\mathrm{a}}$, \\ Robert Gruwez ${ }^{\mathrm{a}}$, and Kris Verheyen ${ }^{\mathrm{a}}$
}

\begin{abstract}
${ }^{a}$ Laboratory of Forestry, Department of Forest and Water Management, Ghent University, Geraardsbergsesteenweg 267, B-9090 Melle-Gontrode, Belgium

${ }^{\mathrm{b}}$ Department of Animal Health, Institute of Tropical Medicine, Nationalestraat 155, B-2000 Antwerp, Belgium ${ }^{\mathrm{c}}$ Department of Veterinary Tropical Diseases, Faculty of Veterinary Science, University of Pretoria, Onderstepoort 0110, South Africa

*Corresponding author: Wesley.Tack@UGent.be; tel.: +32 (0)9 26490 30; fax: +32 (0)9 2649092
\end{abstract}

\section{Abstract}

A large fraction of the forests in northern Belgium consists of homogeneous pine stands on nutrientpoor and acid sandy soils. However, in common with many other parts of Europe, the current forest management aims at increasing the share of deciduous and mixed forests. This might create favourable habitats for the tick Ixodes ricinus, which is Europe's main vector of Borrelia burgdorferi sensu lato, the causative agent of Lyme borreliosis in humans. Considering the threat to human health, it is important to know which factors regulate tick abundance. The influence of local habitat and landscape variables on the abundance of $I$. ricinus ticks were studied by collecting questing larvae, nymphs, and adults at 176 locations in forests in the Campine region (northern Belgium). Both I. ricinus ticks and B. burgdorferi spirochetes occurred throughout the study area, which means that the entire region represents an area of risk for contracting Lyme borreliosis. At the forest stand level, the main tree species and the shrub cover significantly affected the abundance of all life stages of $I$. ricinus. The abundance was higher in oak stands compared to pine stands, and increased with increasing shrub cover. Additionally, at the landscape level, a positive effect was found for forest edge length but not for forest cover. These patterns may be explained by the habitat preferences of the tick's main hosts. Our results indicate that forest conversion might indeed create suitable habitats for ticks, which highlights the need for intensive information campaigns and effective tick control measures.

Key words: Ixodes ricinus, Borrelia, habitat, landscape, deer 
Ticks are parasites of major economic and medical importance due to their role as vector of many pathogenic organisms affecting humans, domesticated animals, and wildlife worldwide (Jongejan and Uilenberg, 2004). Lyme borreliosis, also known as Lyme disease, is an infection caused by spirochetes belonging to the Borrelia burgdorferi sensu lato (s.l.) complex and is by far the most common tick-borne zoonotic disease in the northern hemisphere. In Europe, this infection is predominantly transmitted through the bite of the sheep tick, Ixodes ricinus (Parola and Raoult, 2001; Piesman and Gern, 2004). Ticks acquire the pathogen by feeding on infected vertebrate hosts and can pass the infection on to other vertebrate hosts or humans during the next blood meal. Especially people working in forests and people visiting forests for recreational purposes are at high risk of infection (Cisak et al., 2005). In recent years, the number of reported cases of Lyme borreliosis has increased significantly throughout Europe. A greater awareness of the disease certainly plays an important role, but it is commonly assumed that the observed increase in human cases reflects a true increase in incidence, related to expansion in density and range of tick populations (Sood et al., 2011). A better understanding of the main ecological factors governing the distribution and abundance of ticks is therefore a prerequisite in developing an integrated strategy to reduce human incidences of Lyme borreliosis.

Adequate vegetation cover, providing protection against adverse environmental conditions, and access to host animals for feeding and reproduction are essential for the survival and development of $I$. ricinus ticks (see section 2.1 for details). As a result, tick abundance may vary strongly between different habitat types (Gray et al., 1998; Jaenson et al., 2009). Logically, several studies have focused attention on habitat types as indicators of risk of human exposure to ticks. The abundance of I. ricinus is generally higher in forests compared to open habitats such as pastures and moorland, because forests provide a cooler, more humid microclimate as well as forage and shelter for a diverse mix of host species (Lindström and Jaenson, 2003; Ruiz-Fons and Gilbert, 2010; Walker et al., 2001). Furthermore, within forest variation in tick abundance may be important as well. Deciduous forests and mixed forests dominated by deciduous trees-especially those containing oak trees (Quercus spp.) and harbouring a diverse fauna, including larger mammals such as deer-are generally considered the ideal habitat for I. ricinus. However, coniferous forests in high rainfall areas with a thick, moist litter layer can support high tick densities too (Estrada-Peña, 2001; Gray et al., 1998; Walker et al., 2001). Besides local habitat features, the structure of the surrounding landscape also has a strong potential to influence tick populations through changes in 
abiotic conditions and tick-host dynamics (Ostfeld et al., 2005). In northern Spain, for instance, Estrada-Peña (2003) demonstrated that habitat patches with high tick abundance form part of a network of corridors linking patches of high tick abundance. Patches where the climate and vegetation were highly suitable, but where ticks were absent or present at low abundance, were located far from this main network. These results suggest that tick distribution in a zone is highly affected not only by abiotic variables but also by host movements. In the United States, tick abundance was positively affected by an increase in forest fragmentation, which was attributed to elevated population densities of white-footed mice (Allan et al., 2003; Brownstein et al., 2005). Since the prevention of tick attacks is considered the most effective measure against tick-borne infections, it is important to know where and why ticks are abundant. However, although forest management exerts great influence over the composition and structure of forests at multiple scales, studies on the effects of both local habitat and landscape heterogeneity on tick abundance are scarce.

In the present study, various forest sites throughout the Campine region in northern Belgium were surveyed for the abundance of $I$. ricinus ticks. Collected ticks of the nymphal stage, which is probably the predominant life stage responsible for pathogen transmission, were examined for Borrelia burgdorferi spirochetes. Although the Campine region is a region of high endemicity for Lyme borreliosis (Linard et al., 2007), until now, no field survey of I. ricinus ticks has been carried out at the regional scale. We selected forest stands varying in dominant tree species (pine or oak), shrub cover, and herb layer abundance to determine the importance of those factors. Landscapelevel fragmentation variables were also included to control for potential differences among forest complexes, e.g., related to host dispersal. We specifically addressed the following questions: (i) is the abundance of host-seeking larval, nymphal, and adult I. ricinus ticks higher in oak stands compared to pine stands, (ii) what is the influence of shrub and herb cover on tick abundance, and (iii) what is the influence of forest cover and forest fragmentation on tick abundance?

\section{Material and methods}

\subsection{Study species}

The sheep tick, Ixodes ricinus (Acari: Ixodidae), is the most common tick species associated with Lyme borreliosis in Western Europe. Its life cycle consists of three stages (larva, nymph, and adult) and is usually completed in 2-3 years. Unfed ticks seek hosts using an ambush strategy, typically ascending low vegetation and awaiting passing host animals from a vantage point. The larvae, 
nymphs, and adult females feed once on a separate host, while the adult males rarely feed at all. Ixodes ricinus ticks parasitize numerous species of mammals, birds, and reptiles, some of which function as reservoir for the Lyme borreliosis bacterium (Comstedt et al., 2006; Humair and Gern, 1998; Kurtenbach et al., 1998), but adult females prefer larger mammal hosts, ungulates in particular, to feed successfully and reproduce (Gray, 1998; Parola and Raoult, 2001). Ticks are vulnerable to desiccation during the non-parasitic (off-host) phases of their life cycle and must return to the moist litter layer periodically to rehydrate (Lees, 1946). They require a relative humidity of at least $80 \%$ at the base of the vegetation throughout the year (Kahl and Knülle, 1988) and, consequently, are confined to habitats with a moist litter layer. Because of their limited mobility, Ixodes ticks cannot actively disperse to find suitable habitat. Instead, they rely on the movements of their hosts for dispersal.

\subsection{Study area}

Our study was carried out at 21 forest sites in the Campine ecoregion, situated in the provinces of Antwerp and Limburg in the north-eastern part of Flanders, Belgium (Fig. 1). The climate is subatlantic. The mean annual precipitation amounts to $799 \mathrm{~mm}$ and is evenly distributed throughout the year, with mean monthly precipitation ranging from $53 \mathrm{~mm}$ in March to $79 \mathrm{~mm}$ in July. The mean annual temperature is $9.0^{\circ} \mathrm{C}$, with minimum and maximum mean monthly temperatures of $1.4^{\circ} \mathrm{C}$ in January and $16.7^{\circ} \mathrm{C}$ in July, respectively (Royal Meteorological Institute of Belgium, URL http://www.kmi.be/, accessed 5 July 2011). Forest cover amounts to $16.2 \%$ in Antwerp and 20.6\% in Limburg. The ecoregion's characteristic forests are secondary pine plantations - mainly of Scots pine (Pinus sylvestris) and, to a lesser extent, Corsican pine (P. nigra subsp. laricio) —on nutrientpoor and acid sandy soils, most of which were established in the $19^{\text {th }}$ century and the first half of the $20^{\text {th }}$ century on former heathlands. The coniferous stands are interspersed with deciduous stands of pedunculate oak (Quercus robur), red oak (Q. rubra), common beech (Fagus sylvatica), silver birch (Betula pendula), and downy birch (B. pubescens). The most common species in the shrub layer and among the seedlings are rowan (Sorbus aucuparia), black cherry (Prunus serotina), alder buckthorn (Frangula alnus), pedunculate oak, red oak, and silver birch. The ground vegetation consists of a mixture of grasses, ferns, dwarf shrubs, herbs, and mosses, mainly Deschampsia flexuosa, Molinia caerulea, Dryopteris dilatata and D. carthusiana, Rubus fruticosus agg., Vaccinium myrtillus, Calluna vulgaris, Lonicera periclymenum, Eurhynchium praelongum, Brachythecium rutabulum, and Plagiothecium curvifolium (Waterinckx and Roelandt, 2001). Local vertebrate hosts of nymphal and female ticks are large and medium-sized mammals such as roe deer (Capreolus 
capreolus), red fox (Vulpes vulpes), European hare (Lepus europaeus), mustelid species such as the least weasel (Mustela nivalis) and the European pole cat (Mustela putorius), red squirrel (Sciurus vulgaris), and European hedgehog (Erinaceus europaeus) (Verkem et al., 2003), the latter being an important competent reservoir of B. burgdorferi (Gern et al., 1997; Gray et al., 1994). Very common small mammalian hosts for larvae include pygmy shrew (Sorex minutus), common shrew (Sorex araneus), and various small rodents such as wood mouse (Apodemus sylvaticus), bank vole (Myodes glareolus), and field vole (Microtus agrestis) (Verkem et al., 2003). Several species of mice, voles, and shrews have been shown to be competent reservoirs of the Lyme borreliosis spirochetes (Kurtenbach et al., 1998).

\subsection{Forest stand selection and local habitat and landscape characterization}

At each of the 21 forest sites, 5-15 forest stands were selected for tick sampling. Our general aim was to select pine- and oak-dominated stands at each forest site, both with and without a substantial shrub layer. Only forest stands on poor sandy soils where the relative contribution of Pinus spp. or Quercus spp. to the total cover of the tree layer was greater than or equal to $70 \%$ were considered suitable for our study. Care was taken to select forest stands where the herbaceous layer was dominated by $D$. flexuosa, M. caerulea, D. dilatata, or V. myrtillus to maintain a comparable blanket contact when sampling for ticks. Forest stands with a dense bracken fern (Pteridium aquilinum) understory were avoided because this vegetation can seriously hamper tick collection, especially during summer when the bracken foliage is abundant (Tack et al., 2011). A total of 176 forest stands were sampled, 109 of which were pine stands and 67 were oak stands. Of the selected forest stands, $37 \%$ had less than $10 \%$ shrub cover (35 pine and 30 oak stands), $30 \%$ had a shrub cover of $10-50 \%$ (35 pine and 17 oak stands), and $33 \%$ had more than $50 \%$ shrub cover (39 pine and 20 oak stands). In each forest stand, the percentage cover of the tree layer $(>7 \mathrm{~m})$, shrub layer (1-7 m), and herb layer $(<1 \mathrm{~m})$ was estimated visually. The following local habitat measurements were used for the analysis: main tree species (pine or oak), shrub cover, and herb cover.

The digital forest cover map (Afdeling Bos en Groen, 2001a) and the GIS software package Arcview 3.1 (ESRI, 2004) were used to calculate landscape variables within a circular buffer created at the centre of each forest site. A buffer radius of $3 \mathrm{~km}$ was chosen, which defined a buffer at each site large enough to contain all forest stands visited for tick sampling at that particular site and small enough to minimize the degree of overlap between the buffers. Landscape variables were also calculated using buffer sizes of 1 and $2 \mathrm{~km}$. These buffer sizes were selected based on the results of Kie et al. (2002) and Anderson et al. (2005). They found that correlation between certain 
landscape variables and the size of home range and movements of ungulates occurred at large spatial scales (i.e., radii of $2-3 \mathrm{~km}$ ) but not at smaller spatial scales (i.e., radii of $\leq 1 \mathrm{~km}$ ). We calculated the following landscape variables: the percentage of forest cover, the number and mean size (ha) of forest patches, and the total forest edge length $(\mathrm{km})$. We defined forest patches as areas of continuous tree canopy, with a minimum area of $0.5 \mathrm{ha}$, a minimum width of $25 \mathrm{~m}$, and a minimum canopy cover of $20 \%$. Forest edges were defined as the boundary between forest and any other land cover type, mainly agricultural fields, meadows, grasslands, heathlands, roads, and residential areas.

\subsection{Tick sampling}

Questing ticks were sampled from the vegetation by drag sampling, using a white flannel blanket (1 $\mathrm{m} \times 1 \mathrm{~m}$ ) attached to a wooden dowel. An entire-blanket was used as described by Tack et al. (2011). Each forest stand was visited once between 4 July and 8 September 2009. This time period was chosen because it corresponds to the period during which all life stages, including larvae, were found questing in the study area (Tack et al., 2011). We specifically wanted to include larvae in our study, as their presence in a given location is a good indication of the presence of large maintenance hosts (e.g., deer), which implies that the ticks are part of an established population. Furthermore, the weather conditions were favourable during the two-month sampling period. The minimum daily temperature ranged from 9.9 to $19.7^{\circ} \mathrm{C}\left(\right.$ mean $\left.=14.2^{\circ} \mathrm{C}, \mathrm{SD}=2.3^{\circ} \mathrm{C}\right)$, the maximum daily temperature ranged from 16.7 to $33.4^{\circ} \mathrm{C}\left(\right.$ mean $\left.=23.7^{\circ} \mathrm{C}, \mathrm{SD}=3.5^{\circ} \mathrm{C}\right)$, and the daily precipitation ranged from 0 to $16.8 \mathrm{~mm}($ mean $=1.8 \mathrm{~mm}, \mathrm{SD}=3.5 \mathrm{~mm})$ (Klein Tank et al., 2002). Forest types were sampled in random order to eliminate temporal bias and sampling was performed on dry and non-windy days during day time (between 10:00am and 05:00pm) when vegetation was dry. In a prior study, which was conducted in a pine forest in the Campine region, the time of day of tick sampling did not appear to have a significant effect on tick abundance (Tack et al., 2011, unpublished results). Four 1-minute blanket drags were established at random in each stand. Each 1minute drag covered about $25 \mathrm{~m}$ of distance. After each drag, larvae, nymphs, and adults were removed from the blanket using forceps and stored in vials containing $70 \%$ ethanol for later identification and counting in the laboratory. The sampled ticks were identified morphologically with a stereo-microscope using the identification keys of Hillyard (1996). 


\subsection{Identification of Borrelia infections}

A total of five hundred nymphs were used for further molecular analysis of the presence of $B$. burgdorferi s.l. spirochetes. We did not identify the Borrelia genospecies. Instead, only screening up to species level was performed to get an idea of the overall infection prevalence. The analysis was carried out on five pools (five nymphs per pool) for each of twenty forest sites. One forest site was excluded due to the low numbers of nymphs collected. DNA was extracted using the method of Boom et al. (1990). This method is based on the lysing and nuclease-inactivating properties of proteinase $\mathrm{K}$ together with the nucleic acid-binding properties of silica particles. A standard PCR amplification was performed in $25 \mu \mathrm{l}$ reaction mixtures containing $5 \mu \mathrm{l}$ of the extracted DNA, 1.65 $\mathrm{mM} \mathrm{MgCl} 2,0.2 \mathrm{mM}$ of all four dNTPs, $10 \mathrm{pM}$ of two primers (BorrSLospAF/BorrSLospAR) (Demaerschalck et al., 1995), 1 UTaq polymerase enzyme (Promega), and $1 \mu$ Yellow SubTM (GENEO Bioproducts, Hamburg, Germany). After a hot start of $10 \mathrm{~s}$ at $84^{\circ} \mathrm{C}$, an initiation of $4 \mathrm{~min}$ at $92^{\circ} \mathrm{C}$ was performed, then followed by a 40 cycles denaturation-hybridisation-elongation step (30 $\mathrm{s}$ at $92^{\circ} \mathrm{C}, 45 \mathrm{~s}$ at $58^{\circ} \mathrm{C}$, and $60 \mathrm{~s}$ at $72^{\circ} \mathrm{C}$ ). The PCR ended with an extension step of $10 \mathrm{~min}$ at $72^{\circ} \mathrm{C}$. Five $\mu \mathrm{l}$ of each reaction mixture was mixed with $2 \mu \mathrm{l}$ of loading buffer and loaded onto $2 \%$ agarose gels (Sigma) to be examined for the presence of DNA fragments. A $1.5 \mathrm{~kb}$ DNA ladder (MBI Fermentas, Lithuania) was loaded on every gel. The samples were run for $20 \mathrm{~min}$ at $100 \mathrm{~V}$, stained in ethidium bromide for $30 \mathrm{~min}$, washed under running tap water, and photographed under UV illumination.

\subsection{Statistical analysis}

Tick abundance was expressed as the total number of ticks collected per forest stand $(\approx$ number of ticks per $100 \mathrm{~m}^{2}$, based on the transect area). Each life stage (larva, nymph, and adult) was analyzed separately. Because of the hierarchical nature of the survey (176 forest stands clustered by 21 forest sites), the data were analyzed using mixed effects models with forest site as a random effect term and local habitat variables (stand level) and landscape variables (site level) as fixed effects. Adult abundances were modelled with a generalized linear mixed model with a Poisson error distribution and a log link function using the Imer function of the Ime4 library (Bates et al., 2011) in R 2.13.0 (R Development Core Team, 2011). Larval and nymphal abundances were first $\log _{10}(\mathrm{n}+1)$ transformed to approach normality, which was verified using the Kolmogorov-Smirnov test, and subsequently modelled with linear mixed models using the lme function of the nlme library in R (Pinheiro et al. 2011). Full factorial models were first simplified before estimating parameter values and their significance. That is, the fixed effects of local habitat and landscape variables were 
removed one by one from the model, and their chi-square statistic and significance level were estimated using maximum likelihood.

\subsection{Results}

A total of 25,204 I. ricinus ticks were collected, of which 21,502 were larvae, 3,456 were nymphs, and 246 were adults (138 males and 108 females). All life stages of I. ricinus were found at each of the 21 forest sites sampled, with a mean $( \pm \mathrm{SE})$ abundance of $122.2( \pm 14.6)$ larvae, $19.6( \pm 1.8)$ nymphs, and $1.4( \pm 0.1)$ adults per forest stand. Borrelia-positive nymphs were found at 17 out of the 20 forest sites examined. Overall, 38 out of a total of 100 pools tested positive for the presence of $B$. burgdorferi. The estimated mean nymphal infection prevalence was calculated to be $9.1 \%$ with a $95 \%$ confidence interval of 6.6 to $12.2 \%$.

The landscape variables were strongly correlated with each other. Mean forest patch size was positively correlated with forest cover $(r=0.892, P<0.001)$ and negatively correlated with number of forest patches $(r=-0.701, P<0.001)$, while forest edge length was positively correlated with number of forest patches $(r=0.589, P=0.005)$. Forest cover and forest edge length were not linearly correlated, but we did find a significant quadratic relationship ( $r=0.372, P=0.015)$. To avoid problems of multicollinearity, only forest cover and forest edge length were retained for further analysis. Forest cover in the 3-km buffer ranged from 16.5 to $66.2 \%$ with a mean $( \pm \mathrm{SE})$ of $35.1( \pm 2.8) \%$, and total forest edge length ranged from 77.7 to $190.3 \mathrm{~km}$ with a mean $( \pm \mathrm{SE})$ of $130.8( \pm 6.0) \mathrm{km}$. The mean percentage of coniferous and deciduous forest cover in the 3-km buffers was 71 and $29 \%$, respectively.

The linear mixed-effects models revealed significant effects of both local habitat and landscape variables on tick abundance (Table 1). At the forest stand level, the results indicated a highly significant effect of tree species and shrub cover for all three life stages. The herb layer cover and the interaction terms were not related to tick abundance. Tick abundance was significantly higher in oak stands compared to pine stands (Fig. 2). The mean ( \pm SE) abundance of larvae, nymphs, and adults in the pine stands was $77.7( \pm 10.1), 13.0( \pm 1.3)$, and $0.9( \pm 0.1)$, respectively. In the oak stands, the mean abundance was $194.5( \pm 32.8), 30.5( \pm 4.0)$, and $2.2( \pm 0.3)$, respectively. Thus, larvae were 2.5 times more abundant, and both nymphs and adults were 2.4 times more abundant in oak stands. In addition, a significant positive effect of shrub cover was found for all three life stages (Fig. 2). Larvae, nymphs, and adults were respectively 1.7, 2.0, and 1.9 times more abundant in forest stands with high shrub cover than in stands with low shrub cover. Consequently, oak stands 
with high shrub cover yielded 6-7 times more ticks than homogeneous pine stands with little or no shrubs. Furthermore, at the landscape level, a significant positive effect of total forest edge length was found for both nymphs and adults and a marginally positive effect was found for larvae (Table 1). Forest cover had no effect on tick abundance. The same relationships with forest edge length and forest cover were found when the analysis was performed using buffer sizes of 1 and $2 \mathrm{~km}$.

\section{Discussion}

We conducted a large-scale survey of $I$. ricinus ticks in forests on poor sandy soils - the first tick survey in northern Belgium as far as we know- to investigate the effects of local habitat and landscape variables on questing tick abundance. Both I. ricinus ticks and B. burgdorferi s.1. spirochetes occurred throughout the study area, which means the entire region represents an area of risk for contracting Lyme borreliosis. Spirochetes were absent in three of the forest sites, but this was probably due to the small sample size ( 25 nymphs per forest site) and not because of a true absence. The overall mean infection prevalence in host-seeking nymphs was $9.1 \%$, which is consistent with the mean infection prevalence in Europe (10.1\%) (Rauter and Hartung, 2005). We wish to emphasize the fact that we did not identify the Borrelia genospecies, which could be considered a shortcoming of our study. However, B. afzelii and B. garinii are the most common Borrelia species in Europe (Rauter and Hartung, 2005) and are both known to be responsible for causing Lyme borreliosis in humans. The genospecies B. valaisiana may also be very common, especially in Western Europe, but a number of studies have provided evidence that this genospecies may also be pathogenic for humans (Rijpkema et al., 1997; Ryffel et al., 1999).

Although each forest stand was sampled only once and we could not take into account the seasonal variation in tick abundance, our study does provide important information about the habitat preferences of $I$. ricinus ticks and the influence of landscape structure on tick abundances in summer, when most people visit forests for recreation. Our results confirm the importance of forest type and forest edge on the distribution and abundance of I. ricinus ticks. Consistent with previous studies (Estrada-Peña, 2001; Lindström and Jaenson, 2003), we found a higher abundance of ticks in oak stands compared to pine stands and a higher tick abundance in fragmented forest sites with a high amount of forest edge habitat, which is most likely related to more optimal environmental conditions and a higher density and activity of the tick's main hosts. Many prior studies have stressed the importance of deer in maintaining tick populations: Gray et al. (1992) and Pichon et al. (1999) for I. ricinus in Europe and Duffy et al. (1994) and Stafford et al. (2003) for I. scapularis in the United States. Roe deer are the most common large mammals in the study area and, thus, are 
probably the most important hosts for adult ticks. They most likely play a pivotal role in the observed differences in tick abundance, as deer habitat use largely determines the location where engorged female ticks drop off and lay eggs (Gray et al., 1992; Ruiz-Fons and Gilbert, 2010; Wilson et al., 1990). From spring to autumn - the period of I. ricinus activity - the shrub-rich oak stands in the study area are probably more attractive to roe deer than the homogeneous pine stands, as they provide both high-quality forage and shelter. Although roe deer are considered generalist herbivores, they are highly selective feeders, preferentially feeding on deciduous browse, fruits, and seeds (Tixier and Duncan, 1996). Especially in spring and summer, when female roe deer invest heavily in the care for their offspring (Andersen et al., 1998), coniferous browse is shunned whereas easily digestible forage rich in soluble carbohydrates (e.g., forbs and deciduous browse) is preferred (Cornelis et al., 1999; Tixier et al., 1997). Oak browse is considered highly palatable and acorns can make up a large part of the roe deer diet when they are sufficiently available (e.g., $89 \%$ in a mast year, Maillard and Picard, 1987). Roe deer also require appropriate habitat for birthing and fawn rearing during spring and summer, with enough cover and concealment to hide fawns against potential predators and to protect them from adverse influences of microclimate (Linnell et al., 1999; Tufto et al., 1996; Van Moorter et al., 2009). The positive effect of forest edge length on tick abundance can be explained by the fact that forest edges are high-quality habitats for roe deer as these provide a good interspersion of cover and forage. For example, previous studies reported higher roe deer population densities (Wahlström and Kjellander, 1995), smaller home range sizes (Saïd and Servanty, 2005), and higher utilization rates by female roe deer (Tufto et al., 1996) in edge habitats. Similarly, habitat selection by several small mammal species, which serve as hosts for immature ticks, is strongly influenced by factors related with forage and cover. Bank vole and wood mouse in particular have been identified by several authors as key hosts for larval ticks (Estrada-Peña et al., 2005; Gray et al., 1999; Tälleklint and Jaenson, 1997). Bank vole, a typical forest-dwelling rodent, prefers deciduous plant species to conifers (Hjältén et al., 2004) and prefers forests with well-developed lower vegetation (Ecke et al., 2002; Miklós and Žiak, 2002). Wood mouse, on the other hand, is a habitat generalist which also uses open habitats (Hansson, 1978; Tattersall et al., 2001) and thrives in situations where forests meet open land (García et al., 1998; Geuse et al., 1985; Tellería et al., 1991). In fact, in the study by Boyard et al. (2008), this rodent species was more abundant in the forest-pasture ecotone than inside forests or pastures in a bocage landscape and was highlighted as the major means of transfer of I. ricinus larvae from woodland to pasture. Besides being important hosts for immature ticks, rodents are also important reservoir hosts for B. burgdorferi s.1. (Kurtenbach et al., 1998). Therefore, factors affecting rodent population 
dynamics could also determine the fraction of tick meals taken from them, which could influence the infection prevalence of ticks. Halos et al. (2010) found that B. burgdorferi prevalence was favoured by forest fragmentation in woodlands while in pastures, it was favoured by shrubby vegetation at the perimeter of the pastures, probably because large amounts of edges or shrubs increase the abundance of small vertebrates as reservoir hosts. In the United States, a similar association between populations of competent rodent reservoirs (white-footed mouse) for Lyme borreliosis and ecotones was described (LoGiudice et al., 2003).

In summary, our results show that the Campine region in northern Belgium is indeed a potential risk area for acquiring Lyme borreliosis and that tick abundance was significantly affected by both local habitat and landscape variables, which we postulate is caused by the habitat associations of the tick's main hosts. This means that forest management may strongly influence the suitability of habitats for ticks and, consequently, influence the epidemiology of tick-borne diseases, such as Lyme borreliosis. One of the main goals of the current regional forest management policy is to achieve a balance between economic, ecological, and social values. To achieve this, large areas of homogeneous pine stands are being converted into mixed, un-even-aged stands with multi-layered canopies dominated by native broadleaved species (Afdeling Bos en Groen, 2001b). The main arguments cited in favour of conversion include reduced risk by diversification, sustained soil fertility, biodiversity, and amenity (Brandtberg et al., 2000; Elsasser et al., 2010; Felton et al., 2010; Jactel and Brockerhoff, 2007; Knoke et al., 2008). As forest-based tourism and recreation are likely to increase in the future, there is a growing demand for efficient and effective tick control. The results obtained in our study support the use of vegetation management and landscape modifications as a tool to control vector ticks. Previous studies have already suggested that Lyme borreliosis risk can be reduced by countering forest fragmentation and the accompanying creation of edge habitat and by avoiding residential development adjacent to forests in areas endemic for Lyme borreliosis (Allan et al., 2003; Brownstein et al., 2005; Jackson et al., 2006). In addition, relatively simple interventions such as mowing vegetation and clearing brush along forest trails or other areas of high human activity have been shown to be effective in reducing the local abundance of ticks (Schulze et al., 1995; Wilson, 1986). Creating barriers with woodchips to separate lawns from areas with high tick abundance could also play a role in disease prevention measures (Piesman, 2006). Furthermore, we would like to stress the importance of public health education campaigns to identify high-risk areas for Lyme borreliosis and to promote the use of personal protective measures when entering these areas (e.g., protective clothing, repellent use, routine tick checks). Finally, we would like to remark that determining the risk of $B$. burgdorferi transmission generally involves estimating the 
local abundance of infected host-seeking ticks. The hypothesis that local habitat and landscape variables not only influence tick abundance but also the prevalence of $B$. burgdorferi in ticks is plausible and may present a promising avenue for further research.

4 Acknowledgments

The authors owe special thanks to Karolien Schoonjans for assistance with fieldwork and Hans Matheve for his invaluable help with GIS analysis. We are also grateful to Natuurpunt vzw and the Flemish Nature and Forest Agency (ANB) for the permission to work in the forests. This research was funded by IWT-Flanders, the Institute for the Promotion of Innovation through Science and Technology in Flanders.

\section{References}

Afdeling Bos en Groen, 2001a. Digitale versie van de bosreferentielaag. OC GIS-Vlaanderen, Brussel, België.

Afdeling Bos en Groen, 2001b. Beheervisie voor de openbare bossen. Ministerie van de Vlaamse Gemeenschap, Brussel, België.

Allan, B.F., Keesing, F., Ostfeld, R.S., 2003. Effect of forest fragmentation on Lyme disease risk. Conserv. Biol. 17, 267-272.

Andersen, R., Gaillard, J.M., Liberg, O., San José, C., 1998. Variations in life-history parameters, in: Andersen, R., Duncan, P., Linnell, J.D.C. (Eds.), The European Roe Deer: The Biology of Success. Scandinavian University Press, Oslo, Norway, pp. 285-307.

Anderson, D.P., Forester, J.D., Turner, M.G., Frair, J.L., Merrill, E.H., Fortin, D., Mao, J.S., Boyce, M.S., 2005. Factors influencing female home range sizes in elk (Cervus elaphus) in North American landscapes. Landscape Ecol. 20, 257-271.

Bates, D., Maechler, M., Bolker, B., 2011. Lme4: Linear mixed-effects models using S4 classes. R package version 0.999375-39, URL http://CRAN.R-project.org/package=lme4/. (accessed 5 July 2011). 
Boom, R., Sol, C.J.A., Salimans, M.M.M., Jansen, C.L., Wertheim-van Dillen, P.M.E., van der Noordaa, J., 1990. Rapid and simple method for purification of nucleic acids. J. Clin. Microbiol. 28, 495-503.

Boyard, C., Vourc'h, G., Barnouin, J., 2008. The relationship between Ixodes ricinus and small mammal species at the woodland-pasture interface. Exp. Appl. Acarol. 44, 61-76.

Brandtberg, P.O., Lundkvist, H., Bengtsson, J., 2000. Changes in forest-floor chemistry caused by a birch admixture in Norway spruce stands. For. Ecol. Manage. 130, 253-264.

Brownstein, J.S., Skelly, D.K., Holford, T.R., Fish, D., 2005. Forest fragmentation predicts local scale heterogeneity of Lyme disease risk. Oecologia 146, 469-475.

Cisak, E., Chmielewska-Badora, J., Zwoliński, J., Wójcik-Fatla, A., Polak, J., Dutkiewicz, J., 2005. Risk of tick-borne bacterial diseases among workers of Roztocne National Park (south-eastern Poland). Ann. Agric. Environ. Med. 12, 127-132.

Comstedt, P., Bergström, S., Olsen, B., Garpmo, U., Marjavaara, L., Mejlon, H., Barbour, A.G., Bunikis, J., 2006. Migratory passerine birds as reservoirs of Lyme borreliosis in Europe. Emerg. Infect. Dis. 12, 1087-1095.

Cornelis, J., Casaer, J., Hermy, M., 1999. Impact of season, habitat and research techniques on diet composition of roe deer (Capreolus capreolus): a review. J. Zool. Lond. 248, 195-207.

Demaerschalck, I., Ben Messaoud, A., De Kesel, M., Hoyois, B., Lobet, Y., Hoet, P., Bigaignon, G., Bollen, A., Godfroid, E., 1995. Simultaneous presence of different Borrelia burgdorferi genospecies in biological fluids of Lyme disease patients. J. Clin. Microbiol. 33, 602-608.

Duffy, D.C., Campbell, S.R., Clark, D., DiMotta, C., Gurney, S., 1994. Ixodes scapularis (Acari: Ixodidae) deer tick mesoscale populations in natural areas: Effects of deer, area, and location. J. Med. Entomol. 31, 152-158. 
Ecke, F., Löfgren, O., Sörlin, D., 2002. Population dynamics of small mammals in relation to forest age and structural habitat factors in northern Sweden. J. Appl. Ecol. 39, 781-792.

Elsasser, P., Englert, H., Hamilton, J., 2010. Landscape benefits of a forest conversion programme in Nort East Germany: results of a choice experiment. Ann. For. Res. 53, 37-50.

ESRI, 2004. ArcView 3.1 GIS and mapping software. Environmental Systems Research Institute, Redlands, California.

Estrada-Peña, A., 2001. Distribution, abundance, and habitat preferences of Ixodes ricinus (Acari: Ixodidae) in northern Spain. J. Med. Entomol. 38, 361-370.

Estrada-Peña, A., 2003. The relationships between habitat topology, critical scales of connectivity and tick abundance Ixodes ricinus in a heterogeneous landscape in northern Spain. Ecography 26, $661-671$.

Estrada-Peña, A., Osácar, J.J., Pichon, B., Gray, J.S., 2005. Hosts and pathogen detection for immature stages of Ixodes ricinus (Acari: Ixodidae) in North-Central Spain. Exp. Appl. Acarol. 37, $257-268$.

Felton, A., Lindbladh, M., Bunet, J., Fritz, Ö., 2010. Replacing coniferous monocultures with mixed-species production stands: An assessment of the potential benefits for forest biodiversity in northern Europe. For. Ecol. Manage. 260, 939-947.

García, F.J., Díaz, M., de Alba, J.M., Alonso, C.L., Carbonell, R., de Carrión, M.L., Monedero, C., Santos, T., 1998. Edge effects and patterns of winter abundance of wood mice Apodemus sylvaticus in Spanish fragmented forests. Acta Theriol. 43, 255-262.

Gern, L., Rouvinez, E., Toutoungi, L.N., Godfroid, E., 1997. Transmission cycles of Borrelia burgdorferi sensu lato involving Ixodes ricinus and/or I. hexagonus ticks and the European hedgehog, Erinaceus europaeus, in suburban and urban areas in Switzerland. Folia Parasitol. 44, $309-314$.

Geuse, P., Bauchau, V., Le Boulengé, E., 1985. Distribution and population dynamics of bank voles and wood mice in a patchy woodland habitat in central Belgium. Acta Zool. Fenn. 173, 65-68. 
Gray, J.S., 1998. The ecology of ticks transmitting Lyme borreliosis. Exp. Appl. Acarol. 22, 249258.

Gray, J.S., Kahl, O., Janetzki, C., Stein, J., 1992. Studies on the ecology of Lyme disease in a deer forest in County Galway, Ireland. J. Med. Entomol. 29, 915-920.

Gray, J.S., Kahl, O., Janetzki-Mittman, C., Stein, J., Guy, E., 1994. Acquisition of Borrelia burgdorferi by Ixodes ricinus ticks fed on the European hedgehog, Erinaceus europaeus L. Exp. Appl. Acarol. 18, 485-491.

Gray, J.S., Kahl, O., Robertson, J.N., Daniel, M., Estrada-Peña, A., Gettinby, G., Jaenson, T.G.T., Jensen, P., Jongejan, F., Korenberg, E., Kurtenbach, K., Zeman, P., 1998. Lyme borreliosis habitat assessment. Zent.bl. Bakteriol. 287, 211-228.

Gray, J.S., Kirstein, F., Robertson, J.N., Stein, J., Kahl, O., 1999. Borrelia burgdorferi sensu lato in Ixodes ricinus ticks in a recreational park in south-western Ireland. Exp. Appl. Acarol. 23, 717-729.

Halos, L., Bord, S., Cotté, V., Gasqui, P., Abrial, D., Barnouin, J., Boulouis, H.J., Vayssier-Taussat, M., Vourc'h, G., 2010. Ecological factors characterizing the prevalence of bacterial tick-borne pathogens in Ixodes ricinus ticks in pastures and woodlands. Appl. Environ. Microbiol. 76, 44134420.

Hansson, L., 1978. Small mammal abundance in relation to environmental variables in three Swedish forest phases. Studia Forestalia Suecica 147, 1-40.

Hillyard, P.D., 1996. Ticks of north-west Europe, vol. 52, Field Studies Council, Shrewsbury, United Kingdom.

Hjältén, J., Danell, K., Ericson, L., 2004. Hare and vole browsing preferences during winter. Acta Theriol. 49, 53-62.

Humair, P.F., Gern, L., 1998. Relationship between Borrelia burgdorferi sensu lato species, red squirrels (Sciurus vulgaris) and Ixodes ricinus in enzootic areas in Switzerland. Acta Trop. 69, 213227. 
Jackson, L.E., Hilborn, E.D., Thomas, J.C., 2006. Towards landscape design guidelines for reducing Lyme disease risk. Int. J. Epidem. 35, 315-322.

Jactel, H., Brockerhoff, E.G., 2007. Tree diversity reduces herbivory by forest insects. Ecol. Lett. $10,835-848$.

Jaenson, T.G.T., Eisen, L., Comstedt, P., Mejlon, H.A., Lindgren, E., Bergström, S., Olsen, B., 2009. Risk indicators for the tick Ixodes ricinus and Borrelia burgdorferi sensu lato in Sweden. Med. Vet. Entomol. 23, 226-237.

Jongejan, F., Uilenberg, G., 2004. The global importance of ticks. Parasitology 129, S3-S14.

Kahl, O., Knülle, W., 1988. Water vapour uptake from subsaturated atmospheres by engorged immature ixodid ticks. Exp. Appl. Acarol. 4, 73-83.

Kie, J.G., Bowyer, R.T., Nicholson, M.C., Boroski, B.B., Loft, E.R., 2002. Landscape heterogeneity at differing scales: effects on spatial distribution of mule deer. Ecology 83, 530-544.

Klein Tank, A.M.G., Wijngaard, J.B., Können, G.P., Böhm, R., Demarée, G., Gocheva, A., Mileta, M., Pashiardis, S., Hejkrlik, L., Kern-Hansen, C., Heino, R., Bessemoulin, P., Müller-Westermeier, G., Tzanakou, M., Szalai, S., Pálsdóttir, T., Fitzgerald, D., Rubin, S., Capaldo, M., Maugeri, M., Leitass, A., Bukantis, A., Aberfeld, R., van Engelen, A.F.V., Forland, E., Mietus, M., Coelho, F., Mares, C., Razuvaev, V., Nieplova, E., Cegnar, T., Antonio López, J., Dahlström, B., Moberg, A., Kirchhofer, W., Ceylan, A., Pachaliuk, O., Alexander, L.V., Petrovic, P., 2002. Daily dataset of 20th-century surface air temperature and precipitation series for the European Climate Assessment. Int. J. Climatol. 22, 1441-1453. Data and metadata available at http://eca.knmi.nl/.

Knoke, T., Ammer, C., Stimm, B., Mosandl, R., 2008. Admixing broadleaved to coniferous tree species: a review on yield, ecological stability and economics. Eur. J. For. Res. 127, 89-101.

Kurtenbach, K., Peacey, M., Rijpkema, S.G.T., Hoodless, A.N., Nuttall, P.A., Randolph, S.E., 1998. Differential transmission of the genospecies of Borrelia burgdorferi sensu lato by game birds and small rodents in England. Appl. Environ. Microbiol. 64, 1169-1174. 
Lees, A.D., 1946. The water balance in Ixodes ricinus L. and certain other species of ticks. Parasitology 37, 1-20.

Linard, C., Lamarque, P., Heyman, P., Ducoffre, G., Luyasu, V., Tersago, K., Vanwambeke, S.O., Lambin, E.F., 2007. Determinants of the geographic distribution of Puumala virus and Lyme borreliosis infections in Belgium. Int. J. Health Geogr. 6, 15.

Lindström, A., Jaenson, T.G.T., 2003. Distribution of the common tick, Ixodes ricinus (Acari: Ixodidae), in different vegetation types in southern Sweden. J. Med. Entomol. 40, 375-378.

Linnell, J.D.C., Nijhuis, P.G.T., Teurlings, I.J.M., Andersen, R., 1999. Selection of bed-sites by roe deer Capreolus capreolus fawns in a boreal forest landscape. Wildl. Biol. 5, 225-231.

LoGiudice, K., Ostfeld, R.S., Schmidt, K.A., Keesing, F., 2003. The ecology of infectious disease: effects of host diversity and community composition on Lyme disease risk. Proc. Natl. Acad. Sci. USA $100,567-571$.

Maillard, D., Picard, J.F., 1987. Le régime alimentaire autumnal et hivernal du chevreuil (Capreolus capreolus), dans une hêtraie calcicole, déterminé par l'analyse des contenus stomacaux. Gib. Faune Sauv. 4, 1-30.

Miklós, P., Žiak, D., 2002. Microhabitat selection by three small species in oak-elm forest. Folia Zool. 51, 275-288.

Ostfeld, R.S., Glass, G.E., Keesing, F., 2005. Spatial epidemiology: an emerging (or re-emerging) discipline. Trends Ecol. Evol. 20, 328-336.

Parola, P., Raoult, D., 2001. Ticks and tickborne bacterial diseases in humans: an emerging infectious threat. Clin. Infect. Dis. 32, 897-928.

Pichon, B., Mousson, L., Figureau, C., Rodhain, F., Perez-Eid, C., 1999. Density of deer in relation to the prevalence of Borrelia burgdorferi s.l. in Ixodes ricinus nymphs in Rambouillet forest, France. Exp. Appl. Acarol. 23, 267-275.

Piesman, J., 2006. Response of nymphal Ixodes scapularis, the primary tick vector of Lyme disease spirochetes in North America, to barriers derived from wood products or related home and garden items. J. Vector Ecol. 31, 412-417. 
Piesman, J., Gern, L., 2004. Lyme borreliosis in Europe and North America. Parasitology 129, S191-S220.

Pinheiro, J., Bates, D., DebRoy, S., Sarkar, D., Development Core Team, 2011. Nlme: Linear and nonlinear mixed effects models. R package version 3.1-100.

R Development Core Team, 2011. R: A language and environment for statistical computing. R Foundation for Statistical Computing, Vienna, Austria. ISBN 3-900051-07-0, URL http://www.Rproject.org/. (accessed 5 July 2011).

Rauter, C., Hartung, T., 2005. Prevalence of Borrelia burgdorferi sensu lato genospecies in Ixodes ricinus ticks in Europe: a metaanalysis. Appl. Env. Microbiol. 71, 7203-7216.

Rijpkema, S.G.T., Tazelaar, D.J., Molkenboer, M.J.C.H., Noordhoek, G.T., Plantinga, G., Schouls, L.M., Schellekens, J.F.P., 1997. Detection of Borrelia afzelii, Borrelia burgdorferi sensu stricto, Borrelia garinii and group VS116 by PCR in skin biopsies of patients with erythema migrans and acrodermatitis chronica atrophicans. Clin. Microbiol. Infect. 3, 109-116.

Ruiz-Fons, F., Gilbert, L., 2010. The role of deer as vehicles to move ticks, Ixodes ricinus, between contrasting habitats. Int. J. Parasitol. 40, 1013-1020.

Ryffel, K., Péter, O., Rutti, B., Suard, A., Dayer, E., 1999. Scored antibody reactivity determined by immunoblotting shows an association between clinical manifestations and presence of Borrelia burgdorferi sensu stricto, B. garinii, B. afzelii, and B. valaisiana in humans. J. Clin. Microbiol. 37, 4086-4092.

Saïd, S., Servanty, S., 2005. The influence of landscape structure on female roe deer home-range size. Landscape Ecol. 20, 1003-1012.

Schulze, T.L., Jordan, R.A., Hung, R.W., 1995. Suppression of subadult Ixodes scapularis (Acari: Ixodidae) following removal of leaf litter. J. Med. Entomol. 32, 730-733.

Sood, S.K., O’Connell, S., Weber, K., 2011. The emergence and epidemiology of Lyme borreliosis in Europe and North America, in: Sood, S.K. (Ed.), Lyme Borreliosis in Europe and North America: Epidemiology and Clinical Practice. John Wiley \& Sons, Inc., New Jersey, United States of America, pp. 1-35. 
Stafford, K.C., Denicola, A.J., Kilpatrick, H.J., 2003. Reduced abundance of Ixodes scapularis (Acari: Ixodidae) and the tick parasitoid Ixodiphagus hookeri (Hymenoptera: Encyrtidae) with reduction of white-tailed deer. J. Med. Entomol. 40, 642-652.

Tack, W., Madder, M., De Frenne, P., Vanhellemont, M., Gruwez, R., Verheyen, K., 2011. The effects of sampling method and vegetation type on the estimated abundance of Ixodes ricinus ticks in forests. Exp. Appl. Acarol. 54, 285-292.

Tälleklint, L., Jaenson, T.G.T., 1997. Infestation of mammals by Ixodes ricinus ticks (Acari: Ixodidae) in south-central Sweden. Exp. Appl. Acarol. 21, 755-771.

Tattersall, F.H., Macdonald, D.W., Hart, B.J., Manley, W.J., Feber, R.E., 2001. Habitat use by wood mice (Apodemus sylvaticus) in a changeable arable landscape. J. Zool. Lond. 255, 487-494.

Tellería, J.L., Santos, T., Alcántara, M., 1991. Abundance and food-searching intensity of wood mice (Apodemus sylvaticus) in fragmented forests. J. Mamm. 72, 183-187.

Tixier, H., Duncan, P., 1996. Are European roe deer browsers? A review of variations in the composition of their diets. Rev. Ecol. Terre. Vie. 51, 3-17.

Tixier, H., Duncan, P., Scehovic, J., Yant, A., Gleizes, M., Lila, M., 1997. Food selection by European roe deer (Capreolus capreolus): effects of plant chemistry, and consequences for the nutritional value of their diets. J. Zool. Lond. 242, 229-245.

Tufto, J., Andersen, R., Linnell, J., 1996. Habitat use and ecological correlates of home range size in a small cervid: the roe deer. J. Anim. Ecol. 65, 715-724.

Van Moorter, B., Gaillard, J.M., McLoughlin, P.D., Delorme, D., Klein, F., Boyce, M.C., 2009.

Maternal and individual effects in selection of bed sites and their consequences for fawn survival at different spatial scales. Oecologia 159, 669-678.

Verkem, S., De Maeseneer, J., Vandendriessche, B., Verbeylen, G., Yskout, S., 2003. Zoogdieren in Vlaanderen. Ecologie en verspreiding van 1987 tot 2002. Natuurpunt Studie \& JNMZoogdierenwerkgroep, Mechelen \& Gent, België.

Wahlström, L.K., Kjellander, P., 1995. Ideal free distribution and natal dispersal in female roe deer. Oecologia 103, 302-308. 
Walker, A.R., Alberdi, M.P., Urquhart, K.A., Rose, H., 2001. Risk factors in habitats of the tick Ixodes ricinus influencing human exposure to Ehrlichia phagocytophila bacteria. Med. Vet.

Entomol. 15, 40-49.

Waterinckx, M., Roelandt, B., 2001. De bosinventaris van het Vlaamse Gewest. Ministerie van de Vlaamse Gemeenschap, Afdeling Bos \& Groen, Brussel, België.

Wilson, M.L., 1986. Reduced abundance of adult Ixodes dammini (Acari: Ixodidae) following destruction of vegetation. J. Econ. Entomol. 79, 693-696. 
Table 1. Effect of local habitat and landscape variables on the abundance of Ixodes ricinus larvae, nymphs, and adults $(\mathrm{n}=176)$. A positive effect for Main Tree Species means a higher tick abundance in oak stands compared to pine stands. Abundances were modelled with linear mixed models (larvae and nymphs) and generalized linear mixed models (adults). Significant effects are indicated in bold, $(*) P<0.1, * * P<0.01, * * * P<0.001$.

\begin{tabular}{|c|c|c|c|c|c|c|c|c|c|}
\hline \multirow[b]{2}{*}{ Source of variation } & \multicolumn{3}{|c|}{ Larvae } & \multicolumn{3}{|c|}{ Nymphs } & \multicolumn{3}{|c|}{ Adults } \\
\hline & & $\chi^{2}$ & $P$ & & $\chi^{2}$ & $P$ & & $\chi^{2}$ & $P$ \\
\hline \multicolumn{10}{|l|}{ Local habitat variables } \\
\hline Main tree species & + & 16.66 & $<0.001 * * *$ & + & 29.08 & $<0.001 * * *$ & + & 39.57 & $<0.001 * * *$ \\
\hline Shrub cover & + & 17.81 & $<0.001 * * *$ & + & 25.09 & $<0.001 * * *$ & + & 23.04 & $<0.001 * * *$ \\
\hline Herb cover & & 0.00 & 0.994 & & 1.82 & 0.178 & & 0.05 & 0.823 \\
\hline Main tree $\times$ Shrub & & 0.24 & 0.622 & & 0.45 & 0.503 & & 0.64 & 0.424 \\
\hline Main tree $\times$ Herb & & 0.27 & 0.600 & & 0.14 & 0.707 & & 0.48 & 0.490 \\
\hline Shrub $\times$ Herb & & 0.38 & 0.540 & & 0.24 & 0.626 & & 0.22 & 0.640 \\
\hline \multicolumn{10}{|l|}{ Landscape variables } \\
\hline Forest edge & + & 3.76 & $0.053\left(^{*}\right)$ & + & 9.35 & $0.002 * *$ & + & 8.26 & $0.004 * *$ \\
\hline Forest cover & & 0.09 & 0.766 & & 0.17 & 0.679 & & 2.43 & 0.119 \\
\hline Forest cover $\times$ Edge & & 0.00 & 0.984 & & 0.97 & 0.325 & & 1.69 & 0.194 \\
\hline
\end{tabular}

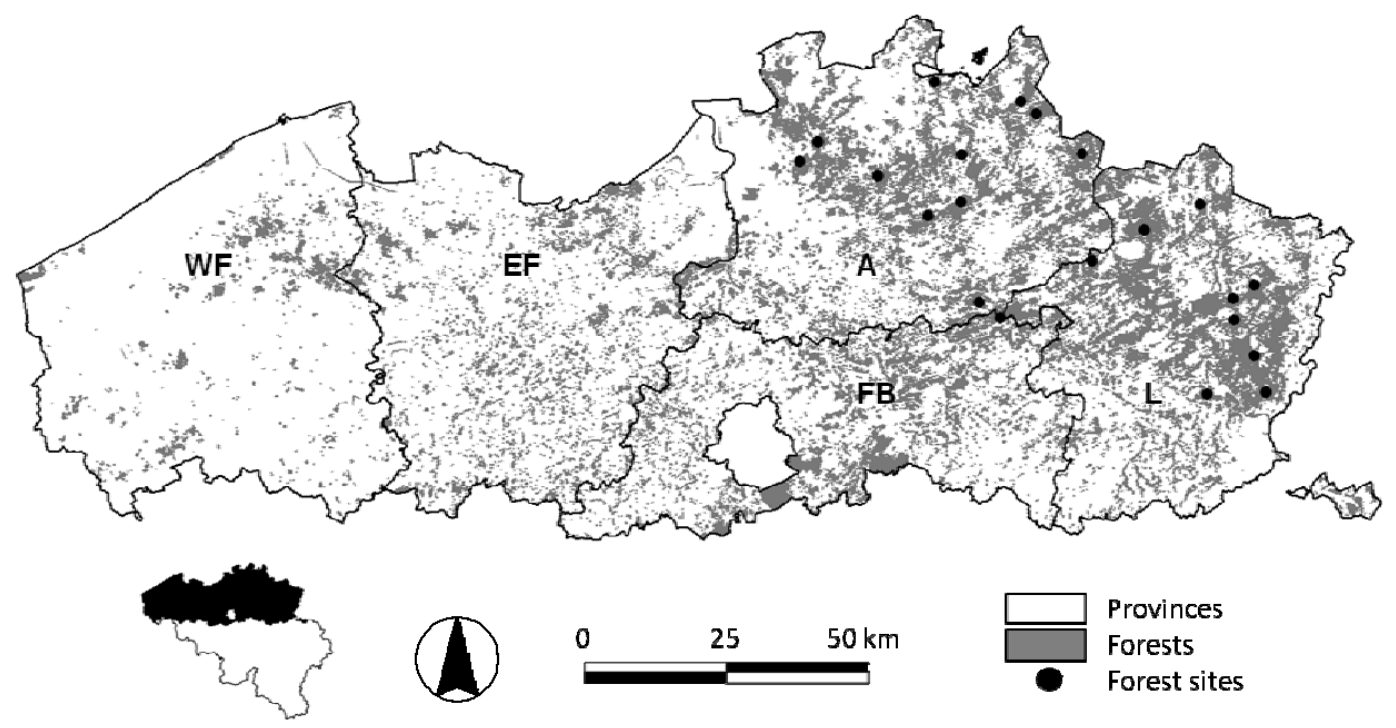

Fig. 1. Map of Flanders (northern Belgium) showing the provinces (A: Antwerp; EF: East-Flanders; FB: Flemish Brabant; L: Limburg; WF: West-Flanders), the forests, and the location of the 21 forest sites where ticks were sampled. 

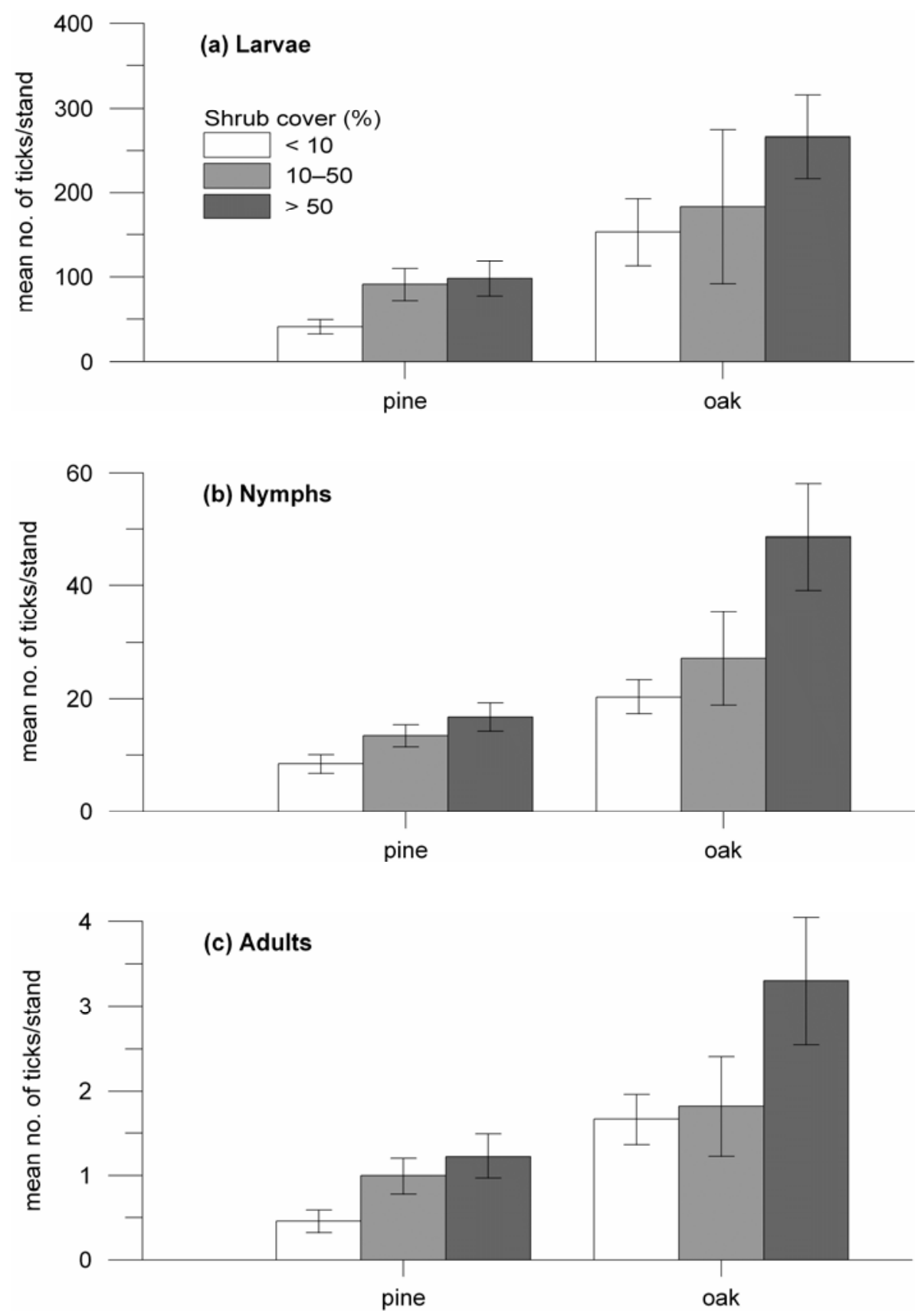

Fig. 2. The effect of shrub cover on the abundance of Ixodes ricinus larvae, nymphs, and adults in pine- and oak-dominated stands. For graphic reasons, the shrub cover estimates were grouped into three classes: low $(<10 \%)$, intermediate $(10-50 \%)$, and high shrub cover $(>50 \%)$. Bars represent the mean number of ticks collected per forest stand and error bars indicate the standard error of the mean. Note the difference in values on the y-axis. 